Terbit online pada laman web jurnal : http://jurnal.iaii.or.id

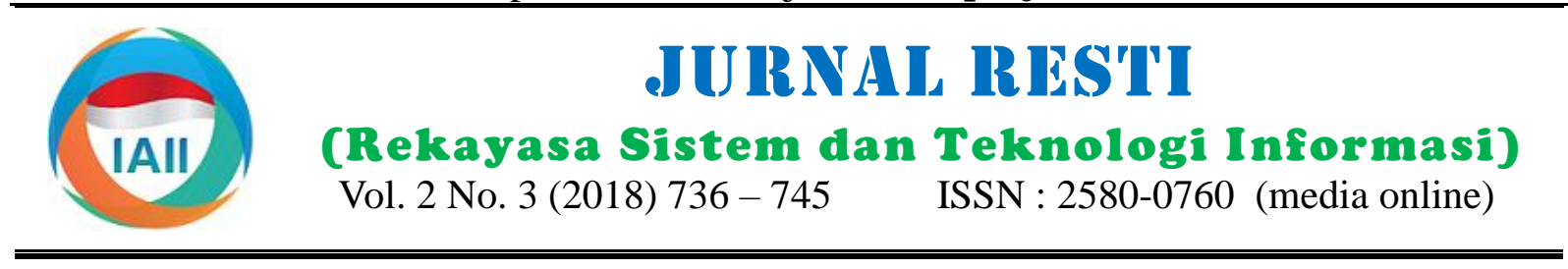

\title{
Klasifikasi Citra X-Ray Diagnosis Tuberkulosis Berbasis Fitur Statistis
}

\author{
Yudhi Agussationo ${ }^{\mathrm{a}}$, Indah Soesanti ${ }^{\mathrm{b}}$, Warsun Najib ${ }^{\mathrm{c}}$ \\ aProgram Studi Teknik Listrik, Politeknik Jambi, yudhiagussationo@politeknikjambi.ac.id \\ bDepartemen Teknik Elektro dan Teknologi Informasi, Fakultas Teknik, Universitas Gadjah Mada, indah@mti.ugm.ac.id \\ 'Departemen Teknik Elektro dan Teknologi Informasi, Fakultas Teknik, Universitas Gadjah Mada, warsun@ ugm.ac.id
}

\begin{abstract}
Tuberculosis is one of the causes of human death. The results of the x-ray examination of tuberculosis diagnosis can be used as an object in the feature extraction process which is a stage in extracting the characteristics of the object contained in an image of a diagnosis of tuberculosis. In this study used first-order statistic (histogram), first-order Gray-Level Cooccurrence Matrix (GLCM) feature extraction methods, as well as the Principle Component Analysis (PCA). Data research digital x-ray tuberculosis patients from Dr. Sardjito Yogyakarta as 33 patients in 2012. Each 6 normal PA (Posteroanterior), 19 abnormal PA, 4 normal AP (Antero-Posterior), and 4 abnormal AP. This study aims to find the best characteristics contained in the $x$-ray image of tuberculosis diagnosis using statistical texture analysis obtained from features found in feature extraction methods. Identified features: variance, standard deviation, skewness, kurtosis, contrast and energy. Classification uses 33 test data are built using the Multi Layer Perceptron (MLP) method, while the output is a normal and abnormal image. The results showed that the accuracy classification used Histogram (81,81\%), GLCM (96,96\%), PCA (81,82\%), and combination GLCM Histogram (100\%).
\end{abstract}

Keywords: Feature Extraction, Histogram Gray Level Co-occurrence Matrix, Principle Component Analysis

\begin{abstract}
Abstrak
Tuberkulosis merupakan salah satu penyebab kematian manusia. Hasil pemeriksaan $x$-ray diagnosis tuberkulosis dapat dijadikan objek pada proses ekstraksi ciri yang merupakan suatu tahapan dalam mengekstrak ciri/ informasi dari objek yang terdapat pada suatu citra diagnosis tuberkulosis. Pada penelitian ini digunakan metode ekstraksi ciri citra berbasis tekstur statistis orde satu (histogram), orde kedua berbasis Gray-Level Co-occurrence Matrix (GLCM), serta Principle Component Analysis (PCA). Data penelitian diperoleh dari RS Dr. Sardjito Yogyakarta sebanyak 33 citra digital $x$-ray pasien diagnosis tuberkulosis Tahun 2012 masing-masing 6 citra PA (Postero-Anterior) normal, 19 citra abnormal, 4 citra AP (AnteroPosterior) normal, dan 4 citra AP abnormal. Penelitian ini bertujuan mencari ciri terbaik yang terkandung pada citra $x$-ray diagnosis tuberkulosis menggunakan analisis tekstur statistis yang diperoleh dari fitur ciri yang terdapat pada metode ekstraksi ciri berbasis tekstur. Fitur ciri yang teridentifikasi antara lain: varians, std deviasi, skewness, kurtosis, contrast dan energy. Klasifikasi menggunakan data input berupa 33 data uji yang dibangun dengan metode Multi Layer Perceptron $(M L P)$, sedang output berupa citra normal dan citra abnormal. Hasil penelitian menunjukkan bahwa akurasi klasifikasi menggunakan metode Histogram $(81,81 \%)$, metode $\operatorname{GLCM}(96,96 \%)$, metode PCA $(81,82 \%)$, dan metode kombinasi Histogram GLCM (100\%).
\end{abstract}

Kata kunci: Ekstraksi Ciri Tekstur, Histogram, Gray Level Co-occurrence Matrix, Principle Component Analysis

(c) 2018 Jurnal RESTI

\section{Pendahuluan}

Tuberkulosis merupakan penyakit menular yang disebabkan oleh infeksi mycobacterium tuberkulosis complex yang dapat menyebar melalui droplet yang terinfeksi basil tuberkulosis [1]. Tuberkulosis merupakan salah satu penyebab kematian utama penduduk dunia pada umumnya serta penduduk Indonesia khususnya. Tuberkulosis merupakan ancaman serius bagi penduduk dunia. Hal ini dapat dilihat dari gencarnya gerakan-gerakan seperti World Health Organization (WHO), Departemen Kesehatan Republik Indonesia (Depkes-RI), Gerakan Terpadu Nasional Penanggulangan Tuberkulosis (Gerdunas-TB) serta organisasi-organisasi lain di seluruh dunia yang bergerak pada bidang kesehatan khususnya, menjadikan penyakit tuberkulosis sebagai salah satu dari beberapa penyakit yang masuk dalam target penuntasan. 
Kasus tuberkulosis mengalami peningkatan pada tahun merupakan keharusan rutin, sehingga tanpa 2014, diperkirakan 2 juta orang meninggal diseluruh pemeriksaan $x$-ray dianggap kurang lengkap. dunia akibat penyakit tuberkulosis paru dengan total Berdasarkan hasil pemeriksaan x-ray, dapat ditemukan kasus 9.6 juta kasus. Tahun 2015, total jumlah kasus ciri-ciri tuberkulosis. Ekstraksi ciri merupakan bagian tuberkulosis 10,4 juta kasus, dimana tuberkulosis yang sangat penting dalam menggali ciri suatu citra $\mathrm{x}$ termasuk 1,2 juta (11\%) diantara orang yang mengidap ray. Beberapa metode statistis yang digunakan dalam HIV positif sebanyak $90 \%$ dewasa dan $10 \%$ anak-anak mencari ciri seperti histogram, Gray level Codengan penjabaran 56\% pria dan 34\% wanita serta 10\% occurence Matrix (GLCM), dan Principle Component anak-anak. World Health Organization (WHO) tahun Analysis (PCA) belum menghasilkan akurasi klasifikasi 2016 menyatakan bahwa tuberkulosis masih menjadi terbaik. Memperbaiki akurasi klasifikasi dapat topik permasalahan kesehatan dunia, yang mana dilakukan dengan menentukan pemilihan fitur terbaik. tuberkulosis merupakan salah satu penyakit menular Untuk mendapatkan fitur terbaik, dapat dilakukan terbanyak di dunia [1].

Menurut WHO dalam Global Tuberculosis Report (GTR) sebaran kasus tuberkulosis pada tahun 2016 banyak terjadi di wilayah Asia Tenggara (45\%), Afrika (25\%), Timur Mediterania (7\%), Eropa (3\%), dan Amerika (3\%). Terdapat 30 negara di dunia yang mempunyai status angka tuberkulosis tertinggi di dunia (87\%) dari semua perkiraan kasus berdasarkan tingkat insidennya. 7 dari 30 negara tersebut antara lain Indonesia, India, China, Filiphina, Pakistan, Nigeria, dan Afrika Selatan. GTR juga menyatakan bahwa kematian akibat tuberculosis terjadi di Negara berpenghasilan rendah dan menengah [1]. dengan mengkombinasi beberapa fitur yang dihasilkan oleh beberapa metode ekstraksi ciri.

\section{Tinjauan Pustaka}

\subsection{Penelitian Terdahulu}

Penelitian yang berkaitan dengan penyakit tuberkulosis telah banyak dilakukan sebelumnya antara lain: Nani Sylviana pasi, 2018 meneliti tentang Identifikasi Penyakit Tuberkulosis Organ Paru Berdasarkan Citra $X$-ray menggunakan Probabilistic Neural Network $(P N N)$. Ekstraksi ciri menggunakan metode moment invariant. Data citra yang digunakan 105 data latih dan 50 data uji. Hasil penelitian menunjukkan metode yang Tuberkulosis di Indonesia mengalami peningkatan digunakan mampu melakukan identifikasi penyakit kasus mulai 2014 hingga 2016. Pada tahun 2014 tuberculosis dengan akurasi klasifikasi sebesar 96\% jumlah kasus tuberkulosis sebanyak 324.539 meningkat [2].

menjadi 330.729 pada tahun 2015. Merujuk pada tahun 2016 jumlah kasus kembali meningkat menjadi 351.893 kasus. Berdasarkan angka keberhasilan pengobatan kasus tuberkulosis di Indonesia, tahun 2013 angka keberhasilan pengobatan tuberkulosis yaitu $83 \%$ dan mengalami penurunan pada tahun $2014(81,3 \%)$ dari target $88 \%$. Kemudian pada 2015 angka keberhasilan pengobatan tuberkulosis yaitu $84 \%$ dengan angka kesembuhan $78 \%$ yang belum mencapai target nasional yaitu 88\%. Sedangkan pada tahun 2016 angka keberhasilan pengobatan kasus Tuberkulosis di Indonesia menurun yaitu $75,4 \%$ yang masih dibawah target $85 \%$ [1].

Pemeriksaan radiologis merupakan pemeriksaan awal dari berbagai jenis pemeriksaan yang dilakukan. Apabila pemeriksaan radiologis mendapat hasil negatif, maka kemungkinan besar pasien dapat dikatakan negatif mengidap tuberkulosis. Hasil pegujian radiologis dapat memberi gambaran apakah pasien terdiagnosis tuberkulosis atau tidak. Dengan mengetahui ciri-ciri khusus yang terkandung pada citra yang akan diuji, akan memudahkan dokter dalam Iwan Setia, 2009 meneliti tentang studi identifikasi membaca, menganalisis, dan memberi gambaran hasil penyakit tuberkulosis pada paru-paru dengan metode terhadap pengujian citra tersebut. Dokter juga dapat jaringan syaraf tiruan. Pada penelitian ini, dilakukan membedakan citra $x$-ray pasien positif tuberkulosis dan suatu simulasi yang dapat memvisualisasikan pasien negatif tuberkulosis.

Pemeriksaan radiologis dan pengetahuan untuk menilai suatu $x$-ray menyebabkan pemeriksaan $x$-ray

Santony, J, dkk, 2014 meneliti tentang Segmentasi Citra X-ray Thorax Penderita Tuberkulosis Berbasis Clustering dengan Metode Fuzzy C-Means. Hasil penelitian metode segmentasi berbasis clustering dapat melakukan pengelompokan berdasarkan perbedaan nilai piksel dari suatu citra paru sehingga terdeteksi bagian paru yang terkena tuberkulosis dan yang tidak. Data penelitian berupa 30 citra $\mathrm{X}$-ray paru dengan akurasi klasifikasi 85,83\% [3].

Moh. Irwan Sumartono, 2009 meneliti tentang Implementasi Metode Kohonen SOM (Self Organizing Maps) untuk identifikasi penyakit paru-paru terhadap penyakit tuberculosis [4]. Hasil pengujian menunjukkan bahwa program dapat melakukan identifikasi kelainan paru dengan prosentase keberhasilan $100 \%$ dari 10 citra yang diujikan. Parameter yang digunakan untuk mengidentifikasi citra roentgen adalah alfa $=0,001$, error value $=0,0001$, reduction $=0,99$, retries $=30.000$. Adapun data yang digunakan sebagai data latih sebanyak 16 data citra. gelombang suara paru-paru dan identifikasi penyakit tuberkulosis pada paru melalui foto rontgen dada, sehingga dengan adanya visualisasi tersebut dapat dibedakan antara grafik paru-paru normal dan paru-

Jurnal RESTI (Rekayasa Sistem dan Teknologi Informasi) Vol. 2 No. 3 (2018) 736 - 745 
paru yang tidak normal. Penelitian menggunakan untuk membedakan tekstur citra tumor otak, stroke parameter intensitas keabuan untuk foto rontgen dada hemoragik, dan citra normal sehingga menghasilkan berdasarkan amplitudo dan frekuensi untuk suara nilai gold standard berdasarkan ciri-ciri tekstur yang pernapasan, diperoleh parameter jaringan saraf tiruan ada. Pelatihan dan pengujian fitur-fitur tekstur dengan 8 node, alfa $(\alpha)$ 0,8 dan momentum 0,9 dengan menggunakan jaringan syaraf tiruan backpropagation iterasi maksimum 500. Diperoleh hasil identifikasi (JST BP) dengan variasi nilai learning rate. Hasil dengan tingkat keberhasilan $80 \%$ dari 20 data foto penelitian menunjukkan bahwa pengujian terbaik rontgen dan $40 \%$ dari data suara pernapasan [4].

M. Ya'qub Zain, 2010 meneliti tentang identifikasi terdapat pada learning rate 0,3 dengan prosentase kesalahan sebesar $11 \%$.

bakteri tuberkulosis berdasarkan ciri morfologi dan Arif A, 2010 meneliti tentang pengenalan wajah warna [4]. Hasil penelitian antara lain: (1) berhasil menggunakan PCA dan jaringan syaraf tiruan [4]. Hasil dibuat perangkat lunak untuk identifikasi bakteri uji coba program menunjukkan penggunaan metode tuberkulosis berdasarkan ciri morfologi dan warna $P C A$ yang berbasis pada jaringan syaraf tiruan dapat menggunakan image processing dengan metode memberikan tingkat akurasi yang tinggi pada proses pengenalan jaringan syaraf tiruan backpropagation, (2) pengenalan wajah. Semua gambar wajah yang diperoleh akurasi identifikasi bakteri sebesar $86,7 \%$ digunakan dapat dikenali $100 \%$ benar. Dari beberapa dengan metode color and shape processing.

Supatman, 2009 meneliti tentang deteksi pembesaran kelenjar getah bening pada paru dengan pengolahan citra digital untuk mendiagnosa penyakit primer kompleks tuberkulosis (PKTB) [4]. Penelitian ini menerapkan teknik pengolahan citra digital pada data Keaslian penelitian yang dilakukan yakni menerapkan citra hasil pemindai dari foto $x$-ray penderita PKTB. metode berbasis statistis dalam melakukan ekstraksi Data citra hasil pemindai disimpan dalam format fitur citra $x$-ray paru diagnosis tuberkulosis. Metode Tagged Image File (.TIF). Proses Pre-processing citra ekstraksi fitur menggunakan fitur statistis berdasar menggunakan YUV color space, modifikasi histogram, histogram, Gray Level Co-occurence Matrix (GLCM), gaussian filter image noise removal. Deteksi dilakukan dan Principle Component Analysis (PCA). Metode dengan segmentasi nilai threshold dan labeling serta tersebut dipilih karena terbukti dapat membedakan satu mapping citra berdasar data Region of Interest (ROI). ciri citra dengan citra lain, memberikan ciri yang tepat Hasil eksperimen menghasilkan deteksi pembesaran pada proses identifikasi, deteksi, maupun klasifikasi, kelenjar gentah bening pada citra paru sesuai dengan serta tingkat akurasi pengenalan ciri satu citra dengan analisis dokter, pembesaran kelenjar getah bening citra lain memberikan hasil akurasi yang baik.

merupakan ciri khas penyakit PKTB.

Ratnasari Nur Rohmah, 2013 meneliti tentang identifikasi tuberkulosis paru berdasar fitur statistis $x$ ray thorax [5]. Pada penelitian ini digunakan lima fitur statistis berdasakan histogram citra. Fitur-fitur tersebut antara lain: mean, standard deviasi, skewness, kurtosis, dan entropy. Selanjutnya digunakan metode Principle Component Analysis (PCA). Aplikasi untuk identifikasi tuberkulosis paru dibangun menggunakan metode klasifikasi jarak minimum dari citra yang diolah. Data yang digunakan sebanyak 70 data dengan pembagian 30 data citra pasien sehat tanpa penyakit, 10 data citra pasien terinfeksi bronkitis, dan 30 data citra pasien tuberkulosis. Berdasarkan sistem yang dibangun diperoleh 95,7\% tingkat akurasi keberhasilan klasifikasi, 3,33\% tingkat akurasi kesalahan klasifikasi yang diterima, 6,67\% tingkat akurasi kesalahan klasifikasi yang ditolak.

Salmawaty Tansa, 2010 meneliti tentang deteksi tumor otak dan stroke hemoragik pada citra CT scan dengan analisis tekstur gray level co-occurence matriks $(G L C M)$ [4]. Analisis tekstur menggunakan metode intensitas keabuan, sementara $p(f n)$ menunjukkan nilai GLCM pada 4 arah $\left(0^{\circ}, 45^{\circ}, 90^{\circ}, 135^{\circ}\right)$ dengan histogram-nya (probabilitas kemunculan intensitas parameter contrast, correlation, energy, homogeinity tersebut pada citra). 


$$
\sigma=\sqrt{\sum_{n}\left(f_{n}-\mu\right)^{2} p\left(f_{n}\right)}
$$

Std deviasi menunjukkan akar dari suatu variasi elemen pada histogram dari suatu citra.

$$
\alpha_{3}=\frac{1}{\sigma^{3}} \sum_{n}\left(f_{n}-\mu\right)^{3} p\left(f_{n}\right)
$$

Skewness menunjukkan tingkat kemiringan relative kurva histogram dari suatu citra.

$$
\sigma_{4}=\frac{1}{\sigma^{4}} \sum_{n}\left(f_{n}-\pi\right)^{4} p\left(f_{n}\right)-3
$$

Kurtosis menunjukkan tingkat keruncingan relative kurva histogram dari suatu citra.

\subsection{Ekstraksi Ciri Berbasis GLCM}

Pada beberapa kasus metode ekstraksi ciri orde pertama terkadang tidak dapat digunakan dalam mengenali perbedaan antar satu citra dengan lainya. Dalam kasus seperti ini, metode ekstraksi ciri orde dua akan menjadi pertimbangan. Teknik yang digunakan pada metode ini, yakni dengan menghitung probabilitas hubungan ketetanggaan antara dua piksel pada jarak $(d)$ dan orientasi sudut tertentu pada suatu citra.

Ekstraksi ciri statistis orde kedua dilakukan dengan matrik kookurensi atau biasa dikenal dengan Gray Level Co-occurence Matrix (GLCM). Kookurensi berarti kejadian bersama, yakni jumlah kejadian satu level nilai piksel bertetangga dengan nilai piksel lain dalam jarak (d) dan orientasi tertentu. Orientasi dibentuk dalam empat arah dengan interval sudut $0^{\circ}$, $45^{\circ}, 90^{\circ}$, dan $135^{\circ}$, sedangkan jarak antar piksel biasanya ditetapkan pada jarak $(d)=1$ piksel.

Parameter fitur yang terdapat pada metode GLCM antara lain: contrast, correlation, energy, homogeneity, dan entropy. Dalam penelitian ini menggunaka dua fitur yaitu contrast dan energy pada jarak dan interval sudut $0^{\circ}, 45^{\circ}, 90^{\circ}$, dan $135^{\circ}$.

$$
\text { Contrast }=\sum_{i, j}|i-j|^{2} P(i, j)
$$

Contrast menyatakan kandungan variasi lokal pada berjumlah 33 data dengan ukuran file yang berbeda. citra. Semakin tinggi nilai contrast suatu citra maka Dari 33 data citra $x$-ray paru diagnosis tuberkulosis, 6 semakin tinggi tingkat kekontrasan citra tersebut.

$$
\text { Energy }=\sum_{i, j} P(i, j)^{2}
$$

Energy menyatakan tingkat keseragaman piksel-piksel suatu citra. Semakin tinggi nilai energy suatu citra, maka semakin seragam nilai tekstur citra tersebut.

\subsection{Ekstraksi Ciri Berbasis PCA}

$P C A$ merupakan suatu cara mengidentifikasi pola-pola pada data kemudian mengekspresikan data tersebut kedalam bentuk lain untuk menunjukkan perbedaan dan persamaan antar pola tersebut. Prinsip dasar dari algoritma $P C A$ adalah mengurangi satu set data namun Penelitian ini dilakukan secara bertahap mulai dari

tetap mempertahankan sebanyak mungkin variasi tinjauan pustaka dan studi literatur, identifikasi dalam set data tersebut. $P C A$ mentransformasikan data ke dalam koordinat baru, dimana koordinat pertama merupakan principal component $(P C)$ pertama yang diperoleh dari nilai eigenvalue terbesar pertama, koordinat kedua merupakan $P C$ kedua yang diperoleh dari eigenvalue terbesar kedua, dan seterusnya. $P C$ satu dengan yang lain tidak saling berkorelasi dan diurutkan sedemikian rupa sehingga $P C$ yang pertama memuat paling banyak variasi dari himpunan data, sedangkan $P C$ kedua memuat variasi yang tidak dimiliki oleh $P C$ pertama. Tujuan dari penggunaan $P C A$ adalah untuk menyederhanakan variabel yang diamati dengan cara menyusutkan/ mereduksi dimensinya. Reduksi dari dimensi tidak menghilangkan banyak informasi dan tetap menjaga karakteristik data karena $P C A$ bertujuan untuk memperoleh $P C$ yang memiliki nilai eigenvalue terbesar. Ekstraksi ciri PCA berdasar euclidian distance terdekat antara basis data dengan data pengujian yang memiliki nilai eigenvalue.

\section{Metodologi Penelitian}

\subsection{Alat dan Bahan}

Alat yang digunakan: software untuk pra-pengolahan dan ekstraksi ciri. Pra pengolahan menggunakan system requirement $O S$ windows 7 , processor Intel $(R)$ Atom(TM) CPU N2600, RAM 2.00 GB. Pre-processing menggunakan MATLAB tools (version R2010a) dengan system requirement $O S$ windows 7 , any intel or $A M D$ x86 processor supporting SSE2, 1.00 GB for MATLAB only, 3-4 GB for typical installation, RAM $1.00 \mathrm{~GB}$ (direkomendasikan minimal 2.00 GB). Classifier aplikasi Weka 3.7 digunakan sebagai tools untuk klasifikasi fitur citra $x$-ray paru diagnosis tuberkulosis. Microsoft Excel digunakan untuk mensortir dan mengevaluasi data hasil ekstraksi ciri.

Bahan penelitian berupa data citra $x$-ray paru pasien diagnosis tuberkulosis. Data citra $x$-ray paru diperoleh dari RSUP Dr. Sardjito, Yogyakarta. Data citra $x$-ray paru diagnosis tuberkulosis yang diperoleh merupakan data pasien radiologi RSUP Dr.Sardjito Tahun 2012 citra $P A$ normal, 19 citra $P A$ abnormal, 4 citra $A P$ normal, 4 citra $A P$ abnormal. Citra $P A$ (PosteroAnterior), diperoleh melalui penyinaran sumber cahaya yang berada di belakang pasien, sedang pelat film ditempatkan di bagian depan pasien, sedangkan citra AP (Antero-Posterior), diperoleh melalui penyinaran sumber cahaya yang ditempatkan didepan pasien, sedang pelat film ditempatkan dibagian belakang pasien. Subyek penelitian dengan rentang umur berkisar antara 5-60 Tahun. Tabel 1.

\subsection{Jalan Penelitian}


masalah, perancangan sistem, analisis hasil rancangan dan penyusunan laporan seperti yang ditujunkkan pada Gambar 1.

\begin{tabular}{cccc}
\multicolumn{4}{c}{ Tabel 1. Kelompok Citra Diagnosis Tuberkulosis } \\
\hline No & Jenis Citra & Jumlah & Ukuran Citra (Piksel) \\
\hline 1. & PA Normal.PNG & 6 & $256 \times 256$ \\
2. & PA Abnormal.PNG & 19 & $256 \times 256$ \\
3. & AP.PNG & 4 & $256 \times 256$ \\
4. & AP Abnormal.PNG & 4 & $256 \times 256$ \\
\hline
\end{tabular}

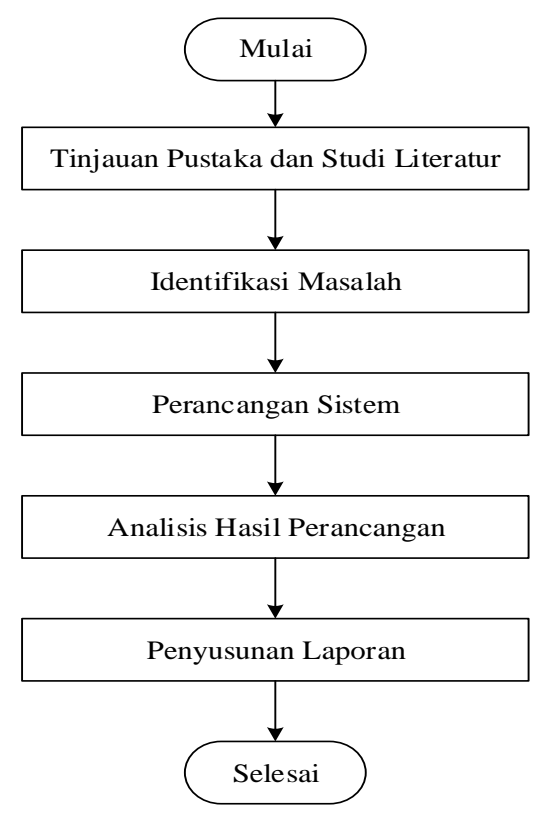

Gambar 1. Jalan Penelitian

\subsection{Sistem Keseluruhan}

Sistem dibangun melalui beberapa tahap yakni akuisisi data, pre-processing, ekstraksi fitur dan analisis hasil. Alur sistem keseluruhan ditunjukkan pada Gambar 2.

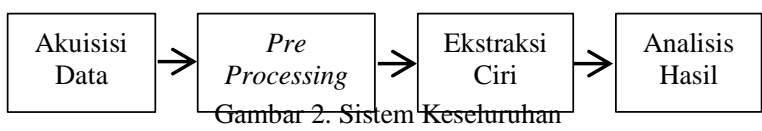

Data citra yang digunakan yaitu 33 data citra $x$-ray paru diagnosis tuberkulosis. Seluruh data citra $x$-ray paru diagnosis tuberkulosis yang diperoleh dari bagian radiologi RSUP Dr. Sardjito Yogyakarta, menggunakan format.$D C M$.

Proses akuisisi data citra yakni merubah data citra dari bentuk DICOM (.DCM) menjadi citra dengan format (.PNG). Proses pre-procesing antara lain: cropping citra, resizing citra, brightness citra, dan konversi citra $R G B$ menjadi grayscale, pengambangan (Thresholding). Tahapan pre-processing citra $x$-ray diagnosis tuberkulosis ditunjukkan pada Gambar 3.

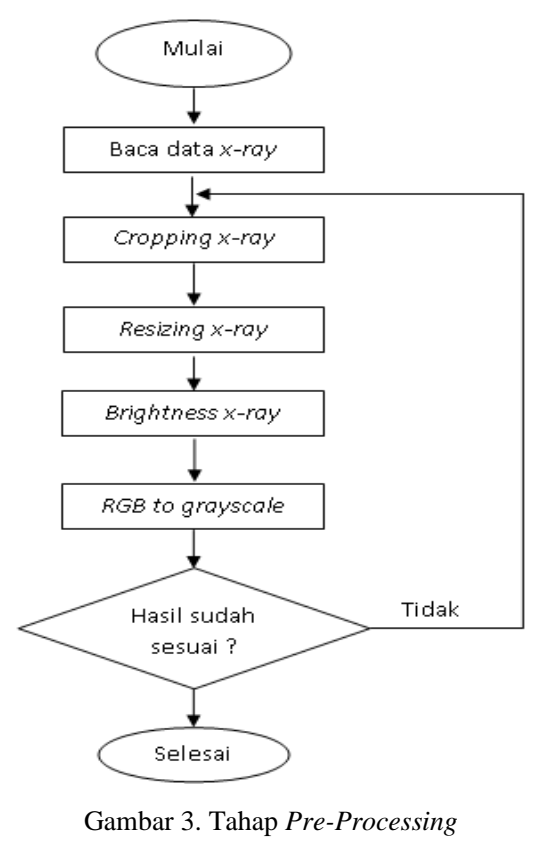

Pertama, membaca data citra $x$-ray paru diagnosis tuberkulosis (.PNG). Kedua, cropping citra $x$-ray paru diagnosis tuberkulosis berdasar pada region of interest yakni di bagian dada. Ketiga, penyeragaman ukuran citra dan penambahan pencerahan citra yang dianggap masih belum seragam. Keempat, pengubahan citra berwarna menjadi citra dengan aras keabuan. Apabila citra hasil keseluruhan sudah sesuai dengan yang diharapkan maka penelitian berlanjut ketahap berikutnya. Kelima, ekstraksi ciri citra menggunakan metode statistis. Namun, Apabila belum sesuai dengan yang diharapkan maka perlu di ulang kelangkah awal pada cropping citra.

\subsection{Ekstraksi Ciri}

Ekstraksi ciri yang digunakan pada penelitian ini berupa pencarian ciri citra menggunakan metode ekstraksi ciri statistis orde satu dan orde dua. Ekstraksi ciri orde satu berbasis histogram, dilakukan perhitungan parameter statistis histogram seperti variance, std deviasi, skewness dan kurtosis.

Metode ekstraksi ciri orde dua berbasis GLCM dengan fitur parameter antara lain: Contrast, dan energy pada interval sudut $0^{\circ}, 45^{\circ}, 90^{\circ}$, dan $135^{\circ}$ Parameter PCA antara lain fitur eigen vector dan eigen value.

Pembentukan ekstraksi ciri berbasis histogram dan GLCM serta PCA ditunjukkan pada Gambar 4 dan 5.

Pertama, membaca data citra hasil pre-processing yang berformat (.PNG). Kedua proses normalisasi matrix $G L C M$. Ketiga, menghitung nilai-nilai fitur-fitur tekstur citra berdasar histogram dan GLCM. Perhitungan fitur tekstur citra antara lain meliputi: variance, std deviasi, skewness, kurtosis, contrast, dan energy. Keempat, seluruh data ciri citra ditampilkan dan dilakukan analisis evaluasi hasil apakah sudah sesuai atau belum. 
Contoh ketidaksesuaian bisa disebabkan kesalahan program atau ciri statistis yang dikeluarkan tidak berupa angka (NaN/ Not a Number). Apabila belum sesuai, ulangi langkah melalui perhitungan metode statistis.

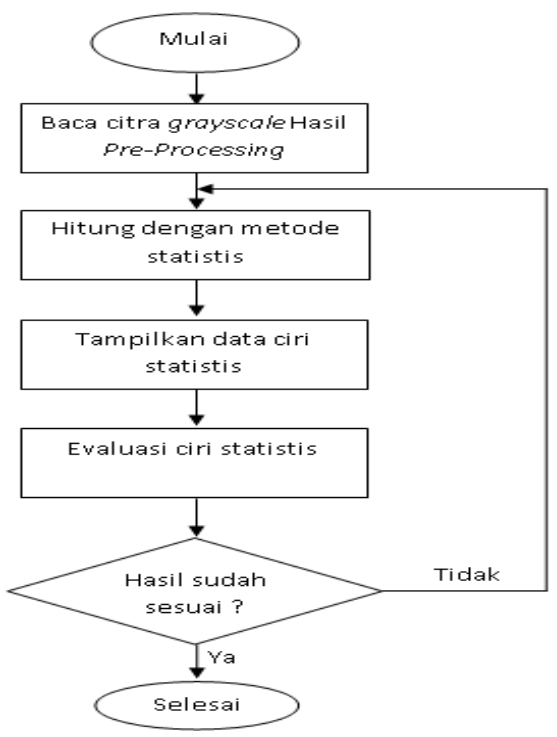

Gambar 4. Ekstraksi Ciri Berbasis Histogram dan GLCM

Ekstraksi ciri berbasis PCA, pertama, akuisisi data citra. Kedua pre-processing. Normalisasi citra dengan histogram menggunakan operasi pengambangan (thresholding) pada citra agar diperoleh citra dengan dua nilai 0 (hitam) dan 1 (putih). Ketiga, ekstraksi ciri menggunakan PCA untuk menemukan pola di dalam sejumlah variabel data dan mengekspresikan data dari variabel-variabel tersebut dengan menonjolkan kemiripan maupun perbedaannya. Keempat, klasifikasi dan pengenalan menggunakan data pembelajaran dan data tanpa pembelajaran yang sudah tersimpan pada database. Mencari eigenvector jarak paling dekat dengan eigenvalue. Kelima, analisis hasil. Mencocokan hasil dari pengenalan pola dengan data yang di simpan sehingga didapat hasil identifikasi sesuai dengan keakuratan data. Ekstraksi ciri berbasis PCA ditunjukkan pada Gambar 5.

\section{Hasil dan Pembahasan}

\subsection{Ekstraksi Ciri Berbasis Histogram}

Untuk fitur variance, nilai rata-rata (average) citra $P A$ normal bernilai lebih besar dibanding citra $P A$ abnormal. Average fitur variance untuk citra $P A$ normal 8,6644, sedangkan untuk citra $P A$ abnormal 5,2094. Rentang data (range) fitur variance citra PA normal bernilai lebih kecil dibanding citra $P A$ abnormal. Range citra $P A$ normal 2,0788, sedangkan citra $P A$ abnormal 2,1081.

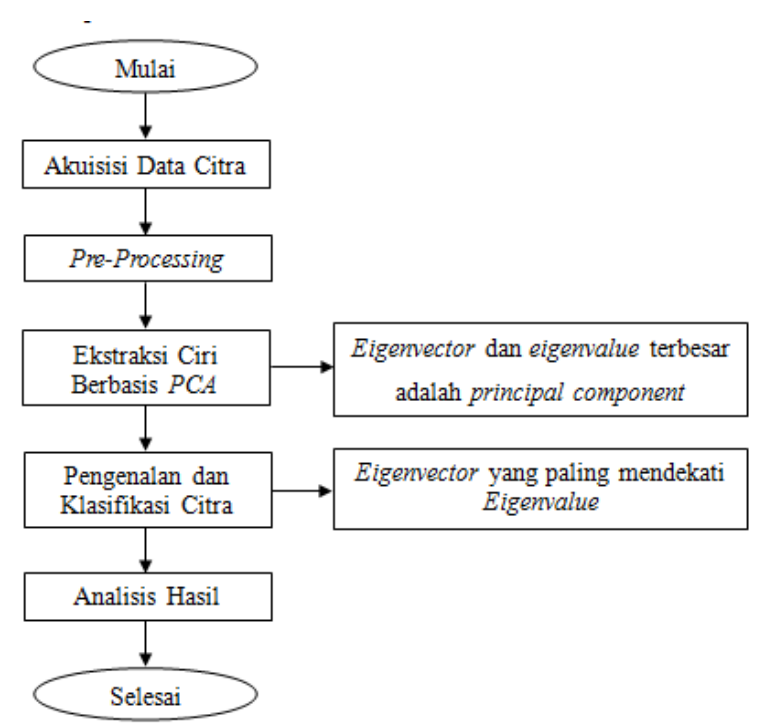

Gambar 5. Ekstraksi Ciri Berbasis $P C A$

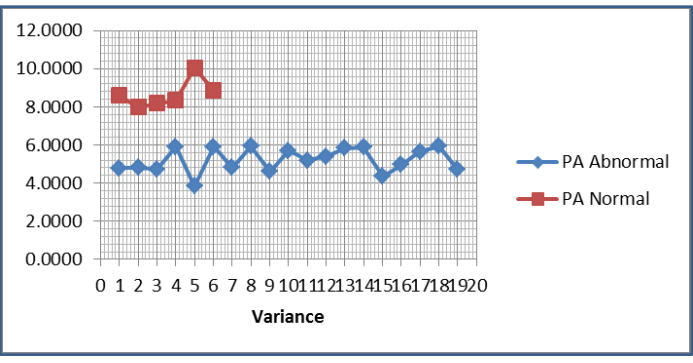

Gambar 6. Fitur Ciri Variance

Untuk fitur std deviasi, average citra $P A$ normal bernilai lebih besar dibanding citra $P A$ abnormal. Average fitur std deviasi citra PA normal 2,9414, sedangkan citra $P A$ abnormal 2,2782. Range fitur std deviasi citra $P A$ normal lebih kecil dibanding citra $P A$ abnormal. Range citra $P A$ normal 0,3468, sedangkan citra PA abnormal 0,4798.

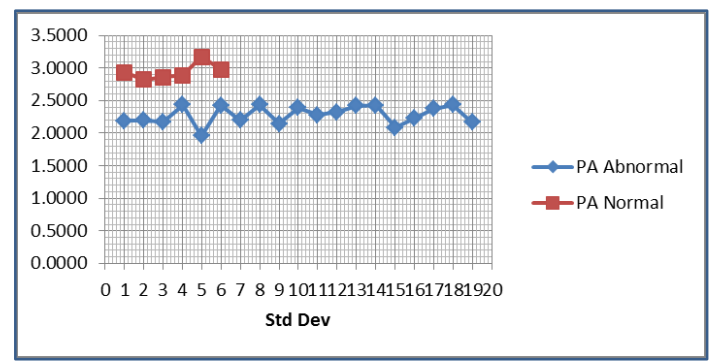

Gambar 7. Fitur Ciri Std Deviasi

Untuk fitur skewness, citra $P A$ normal bernilai lebih besar dibanding citra $P A$ abnormal. Average fitur skewness citra $P A$ normal 0,6937 , sedangkan citra $P A$ abnormal 0,1069. Range fitur skewness citra $P A$ normal lebih kecil dibanding citra $P A$ abnormal. Range citra $P A$ normal 0,4103 , sedangkan citra $P A$ abnormal 0,4878 . 


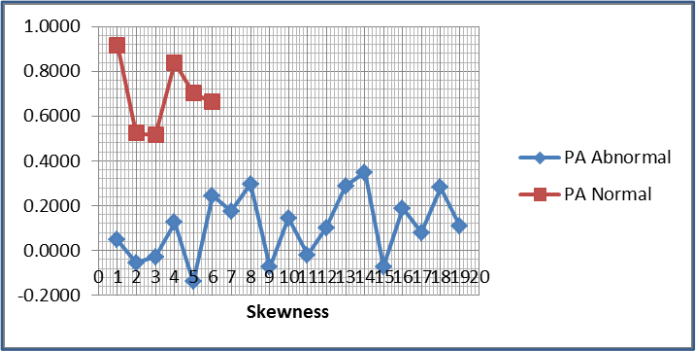

Gambar 8. Fitur Ciri Skewness

Untuk fitur kurtosis citra $P A$ normal bernilai lebih besar dibanding citra $P A$ abnormal. Average fitur kurtosis citra $P A$ normal 2,1072, sedangkan citra $P A$ abnormal 1,4637. Range fitur kurtosis citra $P A$ normal lebih besar dibanding citra $P A$ abnormal. Range citra $P A$ normal 0,9280, sedangkan citra $P A$ abnormal 0,3763.

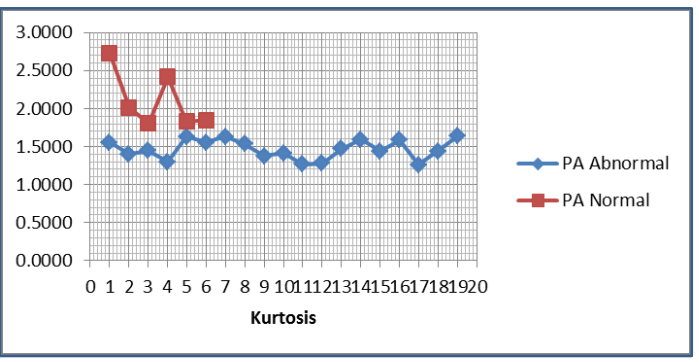

Gambar 9. Fitur Ciri Kurtosis

Secara keseluruhan, average citra $P A$ normal lebih besar dibanding dengan citra $P A$ abnormal pada semua fitur (variance, std deviasi, skewness, dan kurtosis). Range citra $P A$ normal lebih kecil dibanding citra $P A$ abnormal pada fitur variance, std deviasi, dan skewness, sedangkan untuk fitur kurtosis citra $P A$ normal lebih besar dibanding citra $P A$ abnormal.

\subsection{Ekstraksi Berbasis GLCM}

Untuk fitur contrast $O^{\circ}$ (Gambar 10), nilai rata-rata (average) citra $P A$ normal bernilai lebih kecil dibanding citra $P A$ abnormal. Average fitur contrast $O^{\circ}$ untuk citra $P A$ normal 0,0374 , sedangkan untuk citra $P A$ abnormal 0,0659. Rentang data (range) fitur contrast $O^{\circ}$ citra $P A$ normal bernilai lebih kecil dibanding citra $P A$ abnormal. Range citra $P A$ normal 0,0114, sedangkan citra $P A$ abnormal 0,0332.

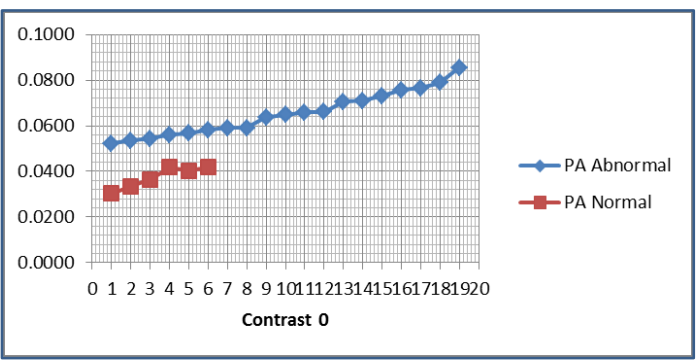

Gambar 10. Fitur Ciri Contrast $0^{\circ}$
Untuk fitur contrast 45$)^{\circ}($ Gambar 11 , average citra $P A$ normal bernilai lebih kecil dibanding citra $P A$ abnormal. Average fitur contrast $45^{\circ}$ citra $P A$ normal 0,0522 , sedangkan citra $P A$ abnormal 0,0913. Range fitur contrast $45^{\circ}$ citra $P A$ normal lebih kecil dibanding citra $P A$ abnormal. Range citra $P A$ normal 0,0177 , sedangkan citra $P A$ abnormal 0,0454 .

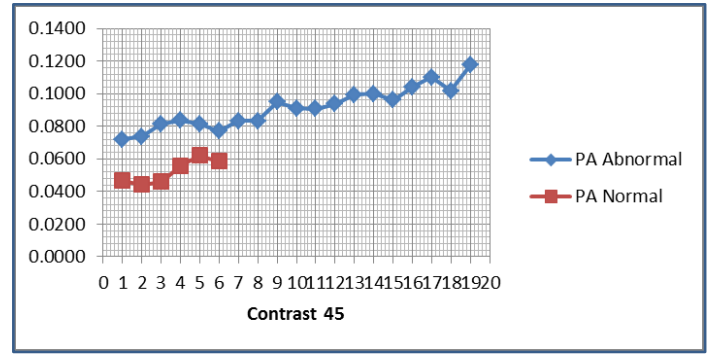

Gambar 11. Fitur Ciri Contrast $45^{\circ}$

Untuk fitur contrast $90^{\circ}$ (Gambar 12), citra $P A$ normal bernilai lebih kecil dibanding citra $P A$ abnormal. Average fitur contrast $90^{\circ}$ citra $P A$ normal 0,0374 , sedangkan citra $P A$ abnormal 0,0672. Range fitur contrast $90^{\circ}$ citra $P A$ normal lebih kecil dibanding citra PA abnormal. Range citra PA normal 0,0103, sedangkan citra $P A$ abnormal 0,0359.

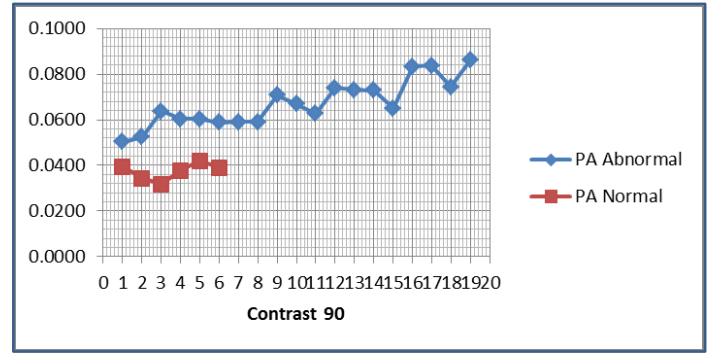

Gambar 12. Fitur Ciri Contrast $90^{\circ}$

Untuk fitur contrast $135^{\circ}$ (Gambar 13) citra $P A$ normal bernilai lebih kecil dibanding citra $P A$ abnormal. Average fitur contrast $135^{\circ}$ citra $P A$ normal 0,0535 , sedangkan citra $P A$ abnormal 0,0923. Range fitur contrast $135^{\circ}$ citra $P A$ normal lebih kecil dibanding citra $P A$ abnormal. Range citra $P A$ normal 0,0122 , sedangkan citra $P A$ abnormal 0,0451 .

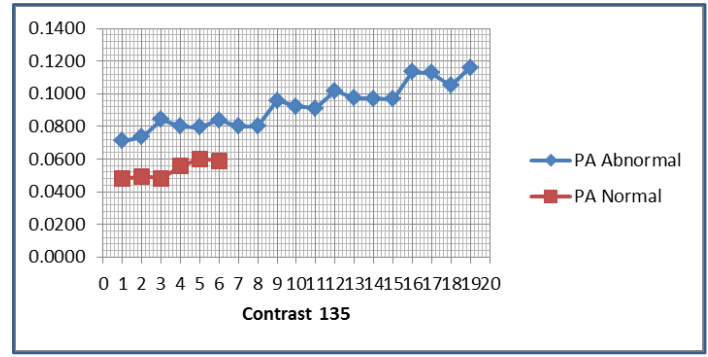

Gambar 13. Fitur Ciri Contrast $135^{\circ}$

Jurnal RESTI (Rekayasa Sistem dan Teknologi Informasi) Vol . 2 No. 3 (2018) 736 - 745 
Secara keseluruhan, average citra $P A$ normal lebih sedangkan citra $P A$ abnormal 0,1960. Range fitur kecil dibanding dengan citra $P A$ abnormal pada semua energy $135^{\circ}$ citra $P A$ normal lebih kecil dibanding citra fitur (contrast $0^{\circ}$, contrast $45^{\circ}$, contrast $90^{\circ}$, dan $P A$ abnormal. Range citra PA normal 0,0238, contrast $135^{\circ}$ ). Range citra $P A$ normal lebih kecil sedangkan citra $P A$ abnormal 0,0459. dibanding citra $P A$ abnormal pada semua fitur contrast $0^{\circ}$, contrast $45^{\circ}$, contrast $90^{\circ}$, dan contrast $135^{\circ}$.

Untuk fitur energy $0^{\circ}$ (Gambar 14), nilai rata-rata (average) citra $P A$ normal bernilai lebih besar dibanding citra $P A$ abnormal. Average fitur energy $0^{\circ}$ untuk citra PA normal 0,2769, sedangkan untuk citra $P A$ abnormal 0,2062. Rentang data (range) fitur contrast $O^{\circ}$ citra $P A$ normal bernilai lebih kecil dibanding citra $P A$ abnormal. Range citra $P A$ normal 0,0402, sedangkan citra $P A$ abnormal 0,0476.

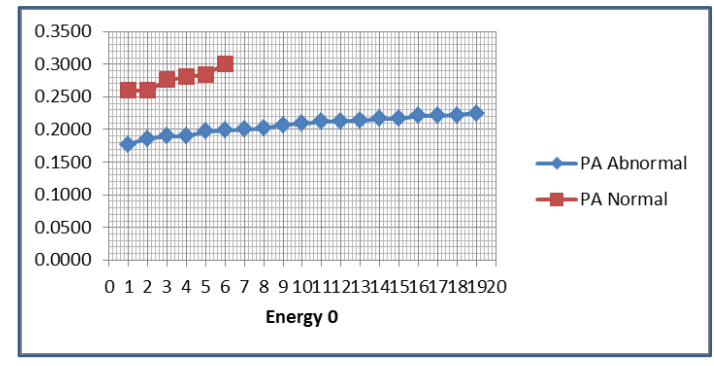

Gambar 14. Fitur Ciri Energy $0^{\circ}$

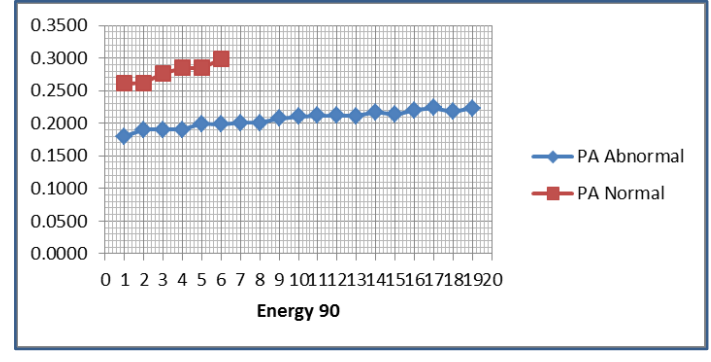

Gambar 16. Fitur Ciri Energy $90^{\circ}$

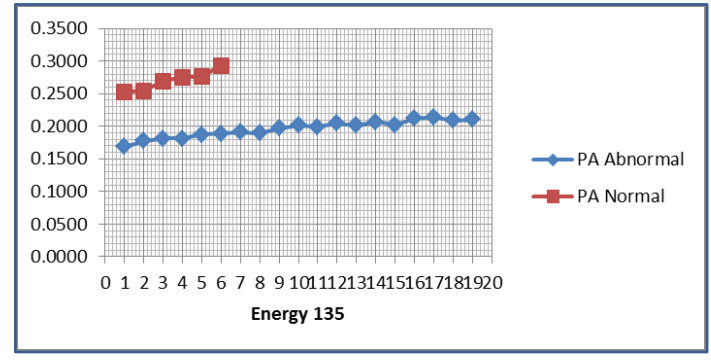

Gambar 17. Fitur Ciri Energy $135^{\circ}$

Untuk fitur energy $45^{\circ}$ (Gambar 15), average citra $P A$ normal bernilai lebih besar dibanding citra $P A$ abnormal. Average fitur energy $45^{\circ}$ citra $P A$ normal 0,2704, sedangkan citra $P A$ abnormal 0,1963. Range fitur energy $45^{\circ}$ citra $P A$ normal lebih kecil dibanding citra $P A$ abnormal. Range citra $P A$ normal 0,0214 , sedangkan citra $P A$ abnormal 0,0449.

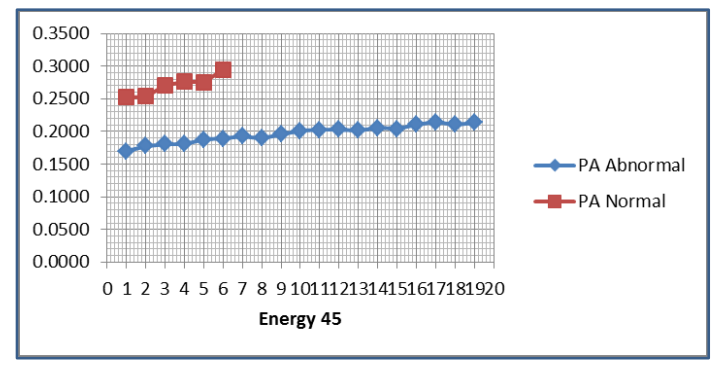

Gambar 15. Fitur Ciri Energy $45^{\circ}$

Untuk fitur energy $90^{\circ}$ (Gambar 16), citra $P A$ normal bernilai lebih besar dibanding citra $P A$ abnormal. Average fitur energy $90^{\circ}$ citra $P A$ normal 0,2780 , sedangkan citra $P A$ abnormal 0,2062. Range fitur energy $90^{\circ}$ citra $P A$ normal lebih kecil dibanding citra PA abnormal. Range citra PA normal 0,0078, sedangkan citra $P A$ abnormal 0,0440.

Untuk fitur energy $135^{\circ}$ (Gambar 17), citra $P A$ normal bernilai lebih besar dibanding citra $P A$ abnormal. Average fitur energy $135^{\circ}$ citra $P A$ normal 0,2702 ,
Secara keseluruhan, average citra $P A$ normal lebih besar dibanding dengan citra $P A$ abnormal pada semua fitur (energy $0^{\circ}$, energy $45^{\circ}$, energy $90^{\circ}$, dan energy $135^{\circ}$ ). Range citra $P A$ normal lebih kecil dibanding citra $P A$ abnormal pada semua fitur energy $0^{\circ}$, energy $45^{\circ}$, energy $90^{\circ}$, dan energy $135^{\circ}$.

\subsection{Ekstraksi Ciri PCA}

Data uji yang digunakan sebanyak data latih yakni 33 citra diagnosis tuberkulosis. Data uji yang digunakan merupakan data latih. Hal ini dikarena keterbatasan data penelitian yang diperoleh peneliti. Proses identifikasi dan klasifikasi citra uji dengan cara membandingkan fitur citra uji dengan citra latih yang memiliki nilai euclidian distance sama atau mendekati citra latih. Sementara untuk identifikasi 33 citra uji dengan 16 fitur $P C$ berdasar euclidian distance diperoleh 27 citra teridentifikasi benar dan 81,82\% akurasi klasifikasi (Tabel 2).

\subsection{Klasifikasi Fitur Citra Diagnosis Tuberkulosis}

Klasifikasi citra $x$-ray paru diagnosis tuberkulosis menggunakan tools classifier dari aplikasi Weka 3.7.7. Klasifikasi citra $x$-ray paru diagnosis tuberkulosis berdasar fitur-fitur dari metode statistis histogram, GLCM, PCA, dan kombinasi histogram GLCM. Terdapat empat kelompok citra yang diklasifikasikan, antara lain: $P A$ normal, $P A$ Abnormal, $A P$ normal, dan $A P$ abnormal. 
Yudhi Agussationo, Indah Soesanti, Warsun Najib

Jurnal RESTI (Rekayasa Sistem dan Teknologi Informasi) Vol . 2 No. 3 (2018) 736 - 745

\begin{tabular}{|c|c|c|c|c|}
\hline $\begin{array}{c}\text { No } \\
\text { Citra }\end{array}$ & Jenis Citra & $\begin{array}{c}\text { PC } \\
\text { Citra } \\
\text { Uji }\end{array}$ & $\begin{array}{c}\text { PC } \\
\text { Terdeteksi }\end{array}$ & Klasifikas \\
\hline 1 & PA Normal & 3.4331 & PC4 & Benar \\
\hline 2 & PA Normal & 5.6821 & PC4 & Benar \\
\hline 3 & PA Normal & 5.3693 & $\mathrm{PC} 14$ & Benar \\
\hline 4 & PA Normal & 7.6212 & $\mathrm{PC} 4$ & Benar \\
\hline 5 & PA Normal & 6.1627 & PC14 & Benar \\
\hline 6 & PA Normal & 4.6237 & $\mathrm{PC} 4$ & Benar \\
\hline 7 & PA Abnormal & 4.0690 & PC14 & Benar \\
\hline 8 & PA Abnormal & 2.7978 & PC4 & Benar \\
\hline 9 & PA Abnormal & 4.8194 & PC14 & Benar \\
\hline 10 & PA Abnormal & 4.4447 & PC14 & Benar \\
\hline 11 & PA Abnormal & 5.9004 & PC16 & Salah \\
\hline 12 & PA Abnormal & 6.4723 & PC14 & Benar \\
\hline 13 & PA Abnormal & 6.5934 & $\mathrm{PC} 4$ & Benar \\
\hline 14 & PA Abnormal & 4.8015 & $\mathrm{PC} 4$ & Benar \\
\hline 15 & PA Abnormal & 5.1207 & PC14 & Benar \\
\hline 16 & PA Abnormal & 8.0130 & $\mathrm{PC} 4$ & Benar \\
\hline 17 & PA Abnormal & 7.8400 & $\mathrm{PC} 14$ & Benar \\
\hline 18 & PA Abnormal & 4.0775 & PC14 & Benar \\
\hline 19 & PA Abnormal & 8.9985 & PC16 & Salah \\
\hline 20 & PA Abnormal & 4.8249 & PC14 & Benar \\
\hline 21 & PA Abnormal & 7.5681 & PC14 & Benar \\
\hline 22 & PA Abnormal & 6.2775 & PC14 & Benar \\
\hline 23 & PA Abnormal & 6.0095 & $\mathrm{PC} 14$ & Benar \\
\hline 24 & PA Abnormal & 6.3108 & $\mathrm{PC} 14$ & Benar \\
\hline 25 & PA Abnormal & 4.4666 & PC14 & Benar \\
\hline 26 & AP Normal & 4.1096 & PC14 & Benar \\
\hline 27 & AP Normal & 7.7582 & PC16 & Salah \\
\hline 28 & AP Normal & 6.5496 & PC4 & Benar \\
\hline 29 & AP Normal & 6.2190 & PC14 & Benar \\
\hline 30 & AP Abnormal & 6.7666 & PC16 & Salah \\
\hline 31 & AP Abnormal & 4.5345 & PC16 & Salah \\
\hline 32 & AP Abnormal & 4.6752 & $\mathrm{PC} 4$ & Benar \\
\hline 33 & AP Abnormal & 6.6146 & PC16 & Salah \\
\hline
\end{tabular}

Input berupa 33 data uji yang dibangun dengan metode Multi Layer Perceptron (MLP), sedang output berupa citra normal dan citra abnormal. Fitur histogram yang

\begin{tabular}{cccl}
\multicolumn{3}{c}{ Tabel 4. Klasifikasi Fitur Ciri $G L C M$} \\
\hline No & Jenis Citra & 8 Fitur & Keterangan \\
\hline 1. & PA Normal & 6 & Energy $0^{\circ}$ \\
2. & PA Abnormal & 19 & Energy $45^{\circ}$ \\
3. & AP Normal & 3 & Energy $90^{\circ}$ \\
& & & Energy $135^{\circ}$ \\
& & Contrast $0^{\circ}$ \\
4. & AP Abnormal & 4 & Contrast $45^{\circ}$ \\
& & Contrast $90^{\circ}$ \\
& & Contrast $135^{\circ}$ \\
\hline & & \\
\hline Akurasi Klasifikasi & $96,96 \%$ & \\
\hline
\end{tabular}

Berdasarkan Tabel 4 terlihat hasil akurasi klasifikasi citra $x$-ray paru tuberkulosis menggunakan metode GLCM sebesar $96,96 \%$. Dari total 33 citra yang diuji, 32 citra teridentifikasi dengan tepat, sedangkan sisanya sebanyak 1 citra uji $(3,03 \%)$ tidak teridentifikasi.

\begin{tabular}{cccl} 
Tabel 5. Klasifikasi Fitur Ciri Kombinasi Histogram GLCM \\
\hline No & Jenis Citra & 8 Fitur & Keterangan \\
\hline 1. & PA Normal & 6 & Variance \\
2. & PA Abnormal & 19 & Std Dev \\
3. & AP Normal & 4 & Skewness \\
& & & Kurtosis \\
& & Energy $0^{\circ}$ \\
& & Energy $45^{\circ}$ \\
& & Energy $90^{\circ}$ \\
4. & AP Abnormal & 4 & Energy $135^{\circ}$ \\
& & Contrast $0^{\circ}$ \\
& & Contrast $45^{\circ}$ \\
& & Contrast $90^{\circ}$ \\
& & Contrast $135^{\circ}$ \\
\hline Akurasi Klasifikasi & $100 \%$ & \\
\hline
\end{tabular}

digunakan antara lain: variance, std deviasi, skewness, Berdasarkan Tabel 5 terlihat hasil akurasi klasifikasi dan kurtosis. Fitur GLCM yang digunakan antara lain: citra $x$-ray paru diagnosis tuberkulosis berdasar metode contrast dan energy masing-masing pada sudut $0^{\circ}, 45^{\circ}$, kombinasi histogram GLCM dengan 12 fitur sebesar $90^{\circ}, 135^{\circ}$. Fitu $P C A$ yang digunakan antara lain: $P C 1,100 \%$. Dari total 33 citra yang diuji, 33 citra atau $P C 2, P C 3, \ldots, P C 16$. Hasil klasifikasi citra $x$-ray paru keseluruhan citra teridentifikasi dan terklasifikasi diagnosis tuberkulosis berdasar histogram diperlihatkan dengan tepat. pada Tabel 2.

\begin{tabular}{cccc}
\multicolumn{4}{c}{ Tabel 3. Klasifikasi Fitur Ciri Berbasis Histogram } \\
\hline No & Jenis Citra & 4 Fitur & Keterangan \\
\hline 1. & PA Normal & 4 & 1.Variance \\
2. & PA Abnormal & 19 & 2.Std Dev \\
3. Skewness \\
4. & AP Normal & 2 & 4.Kurtosis \\
\hline \multicolumn{5}{c}{ Jumlah Abnormal } & 2 & \\
\hline Akurasi Klasifikasi (\%) & 81,81 \\
\hline
\end{tabular}

\begin{tabular}{|c|c|c|c|}
\hline No & Jenis Citra & 4 Fitur & Keterangan \\
\hline 1. & PA Normal & 6 & \multirow{4}{*}{$\begin{array}{l}\text { 1.Variance } \\
\text { 2.Std Dev } \\
\text { 3.Skewness } \\
\text { 4.Kurtosis }\end{array}$} \\
\hline 2. & PA Abnormal & 17 & \\
\hline 3. & AP Normal & 3 & \\
\hline \multirow[t]{2}{*}{4.} & AP Abnormal & 1 & \\
\hline & Jumlah & 27 & \\
\hline \multicolumn{2}{|c|}{ Akurasi Klasifikasi (\%) } & 81,81 & \\
\hline
\end{tabular}

Berdasarkan Tabel 6 terlihat hasil akurasi klasifikasi Berdasarkan Tabel 3 terlihat hasil akurasi klasifikasi citra $x$-ray paru diagnosis tuberkulosis berdasar metode citra $x$-ray paru tuberkulosis menggunakan metode kombinasi histogram GLCM dengan 12 fitur sebesar histogram diperoleh akurasi klasifikasi sebesar 81,81\%. 100\%. Dari total 33 citra yang diuji, 33 citra atau Dari total 33 citra yang diuji, 27 citra teridentifikasi, keseluruhan citra teridentifikasi dan terklasifikasi sisanya sebanyak 6 citra uji $(18,18 \%)$ tidak dengan tepat. teridentifikasi.

Jurnal RESTI (Rekayasa Sistem dan Teknologi Informasi) Vol. 2 No. 3 (2018) 736 - 745 
Tabel 7. Perbandingan Akurasi Klasifkasi Fitur Ciri

\begin{tabular}{cc}
\hline Metode & Akurasi $(\%)$ \\
\hline Histogram & 81,81 \\
GLCM & 96,96 \\
PCA & 81,82 \\
Histogram + GLCM & 100 \\
\hline
\end{tabular}

Berdasarkan Tabel 7 terlihat perbandingan hasil akurasi klasifikasi citra $x$-ray paru tuberkulosis. Sebanyak 33 citra uji dilakukan pada masing-masing metode. Metode berdasar histogram mempunyai akurasi klasifikasi sebesar $81,81 \%$. Metode berdasar GLCM mempunyai akurasi klasifikasi citra sebesar $96,96 \%$. Metode berdasar PCA mempunyai akurasi klasifikasi citra sebesar 81,82\%. Metode Kombinasi histogram GLCM mempunyai akurasi klasifikasi citra sebesar $100 \%$. Metode kombinasi histogram GLCM merupakan metode ekstraksi ciri tekstur gabungan orde satu dan dua (menggabungkan fitur-fitur dari metode histogram Terima kasih kepada Departemen layanan dan dan $G L C M$ ). Semakin banyak fitur yang digabungkan, informasi kesehatan Rumah Sakit dr. Sardjito semakin tinggi pula akurasi klasifikasi citra $x$-ray paru Yogyakarta yang telah berkenan memberikan data citra diagnosis tuberkulosis. Oleh karena itu, metode medis diagnosis tuberkulosis tahun 2011-2012, dan kombinasi histogram GLCM merupakan metode yang seluruh pihak yang telah membantu memberikan tepat dalam menentukan ciri citra $x$-ray diagnosis sumbangsih atas penelitian ini. tuberkulosis menggunakan metode ekstraksi ciri berdasar tekstur statistis.

\section{Kesimpulan}

\subsection{Simpulan}

Metode kombinasi histogram GLCM, lebih baik dari metode histogram, metode GLCM, dan metode PCA dalam mengekstraksi ciri dan mengklasifikasi citra $x$ ray paru diagnosis tuberkulosis berbasis tekstur [4] statistis. Kinerja sistem klasifikasi 33 data uji dalam 4 kelompok berdasar histogram mencapai $81,81 \%$ [5] melalui 4 fitur. Klasifikasi berdasar GLCM mencapai 96,96\% melalui 8 fitur. Klasifikasi berdasar $P C A$ mencapai $81,82 \%$ melalui 16 fitur. Klasifikasi metode kombinasi berdasar histogram GLCM mencapai $100 \%$ melalui 12 fitur. Metode kombinasi histogram GLCM merupakan metode ekstraksi ciri berbasis tekstur statistis yang memiliki akurasi tertinggi dalam menenemuka ciri citra $x$-ray diagnosis tuberkulosis.

\subsection{Saran}

Perlu penelitian lanjutan terkait ekstraksi ciri citra $x$-ray paru diagnosis tuberkulosis menggunakan data yang lebih banyak dan bervariasi. Data ekstraksi ciri $x$-ray paru diagnosis tuberkulosis dapat dicobakan untuk tahap yang lebih jauh seperti klasifikasi maupun identifikasi secara real time/ otomatis.

\section{Ucapan Terima Kasih}

\section{Daftar Rujukan}

[1] Irma Widia Sari, "Faktor-Faktor Yang Berhubungan Dengan Keterlambatan Provider Dalam Pengobatan Tuberkulosis Kota Padang Tahun 2018," 2018.

[2] Soekirman, "Identifikasi Penyakit Tuberkulosis (TB) Organ Paru Berdasarkan Citra X-Ray Menggunakan Probabilistic Neural Network (PNN)," 2014

J. Santony, "Metode Fuzzy C-Means," vol. 1, no. 2, pp. 40-43, 2014.

Y. Agussationo, "Ekstraksi Ciri Citra X-Ray Paru Berbasis Ciri Statistis," Universitas Gadjah Mada, 2016.

R. N. Rohmah, "Computer Aided Diagnosis for Lung Tuberculosis Identification Based on Thoracic X-ray," 2013. 